\title{
Key molecular pathways affected by glaucoma pathology: is predictive diagnosis possible?
}

\author{
Olga Golubnitschaja • Kristina Yeghiazaryan • \\ Josef Flammer
}

Received: 26 April 2010 / Accepted: 31 May 2010/Published online: 29 June 2010

(C) European Association for Predictive, Preventive and Personalised Medicine 2010

\begin{abstract}
Prediction and prevention of glaucoma. Neurodegenerative eye disease glaucoma is the second leading cause of blindness with estimated 67 million patients worldwide. Molecular pathomechanisms of glaucoma demonstrate both a considerable overlap with and remarkable particularities compared to other neurodegenerative disorders e.g. Alzheimer's disease. Identification of pathology-specific biomarker-sets is essential to develop advanced diagnostic approaches and personalised patients' treatment. Subcellular imaging and expression patterns in blood as the reliable platform for early/predictive glaucoma diagnosis. Following key pathways are affected in glaucoma pathology: stress response, apoptosis and DNA-repair, adhesion, blood-brainbarrier-breakdown, tissue remodelling, transcription regulation, multidrug resistance and energy metabolism.
\end{abstract}

Keywords Personalised medicine - Glaucoma $\cdot$ Blood biomarkers · Specific molecular-profiles · Early/predictive diagnosis $\cdot$ Targeted preventive measures

O. Golubnitschaja $(\bowtie) \cdot K$. Yeghiazaryan

Department of Radiology,

Rheinische Friedrich-Wilhelms-University of Bonn,

Sigmund-Freud-Str. 25,

D-53105 Bonn, Germany

e-mail: Olga.Golubnitschaja@ukb.uni-bonn.de

O. Golubnitschaja $\cdot$ K. Yeghiazaryan $\cdot$ J. Flammer

European Association for Predictive,

Preventive \& Personalised Medicine

URL: www.epmanet.eu

J. Flammer

Department of Ophthalmology, University of Basel,

Basel, Switzerland

\section{Particularities of the neurodegenerative disease glaucoma}

Glaucoma is complex neurodegenerative disease the molecular pathomechanisms of which demonstrate both a considerable overlap and remarkable particularities compared to some other neurodegenerative disorders such as Alzheimer's disease. As an example, neuronal thread protein (NTP) demonstrates enhanced expression levels in glaucoma patients against controls [1], the same observation occurred also for Down Syndrome, Alzheimer's and some other diseases [2], indicating axonal lesions as the common feature but giving no information about the corresponding aetiology. Simultaneous monitoring of expressional rates of further $T A U$-protein enables distinction between the pathologies: in contrast to the accumulation of $T A U$-protein characteristic for Alzheimer's disease and other tauopathies, glaucoma patients demonstrate no increase in the target protein expression versus controls [3]. Therefore, the selection of biomarkers specifically affected by glaucoma pathology is of high value creating advanced diagnostic approaches and targeted prevention and individualised treatment.

Glaucoma is a neurodegenerative eye disease andworldwide - the second leading cause of permanent vision loss with estimated 67 million patients worldwide [4]. Glaucomatous optic neuropathy (GON) is characterised by a combination of a loss of retinal ganglion cells and their axons with disease typical optic nerve head (ONH) atrophy (see Fig. 1). An extensive tissue remodelling accompanying GON is very complex and the molecular pathomechanisms of GON are not yet completely clear.

The aetiology of glaucoma and risk factors are only partially known [6, 7], (see Fig. 2).

IOP (intraocular pressure) is considered the most important and only modifiable risk factor in glaucoma. Although 

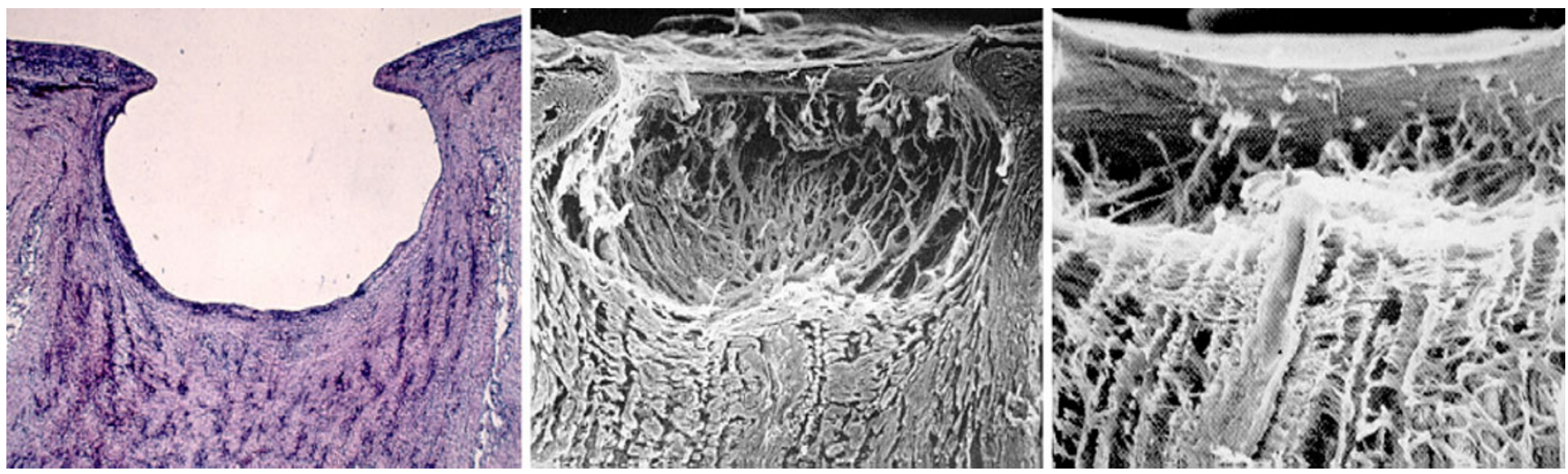

Fig. 1 Characteristic degenerative tissue remodelling by glaucomatous damage [5]

elevated IOP has been shown to be the major risk factor, there is a cohort of patients even at younger ages with normal IOP developing normal-tension glaucoma (NTG) (Fig. 3).

The frequency and incidence of different glaucoma forms vary geographically, depending on race, sex and age [8-10]. A family history of the disease is common among glaucoma patients, suggesting a genetic background for this disorder. The existence of a genetic linkage associated with particular forms of glaucoma is well documented in literature [10-17]. The growing body of evidence suggests the idea that geneticbased approaches in early diagnosis of glaucoma and targeted treatment might yield better results than medical, surgical, and rehabilitation interventions alone [17]. Although mutation research in glaucoma detected some attractive potential targets, the mutated genes found-like TIGR — play a limited role in the pathogenesis of glaucoma and do not explain the usual clinical picture [9, 18-22]. Therefore, pharmacogenetic approaches, if any, would provide only minor success in prediction of glaucoma.

Are there any molecular diagnostic approaches developed to preselect glaucoma-predisposed individuals, to distinguish between glaucoma forms and to estimate a disease progression? We should state a current lack of clinical approaches for early and predictive diagnostics of glaucoma. However, much effort made and recent progress achieved in the identification of disease characteristic molecular patterns

\section{KNOWN RISK FACTORS:}

- IOP

- race

- female gender

- genetics

- myopia

- corneal thickness

- optic disc haemorrhages

- haemodynamics, others

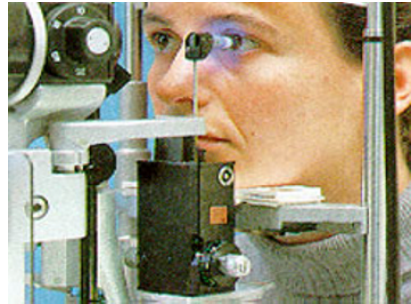

Fig. 2 Risk factors in glaucoma and measurement of intraocular pressure (IOP) [5] should be clearly acknowledged - the issue which is reviewed in this chapter.

\section{Impact of vascular component and relevance of gene} expression patterns in blood for glaucoma pathology

A wealth of literature points to the potential importance of haemodynamics in glaucoma pathology, but randomised controlled trials are not yet available. Healthy individuals with Vasospastic Syndrome demonstrate molecular profiles in blood similar to those of glaucoma patients [23]. Particular predisposition of vasospastic individuals to glaucoma is discussed in the separate review of this journal-issue [24]. Although animal models for glaucoma provided us with useful information about affected molecular pathways and potential targets in the eye, they are barely applicable for non-invasive diagnostics on human being. Since blood is easily accessible, its molecular analysis, in reasonable amounts (few millilitres), may prove practical application in population screening for high-risk subjects. How relevant are gene expression patterns in blood serum and white blood cells for the eye? Glaucoma patients frequently exhibit abnormal T-cell subsets and increased titres of serum

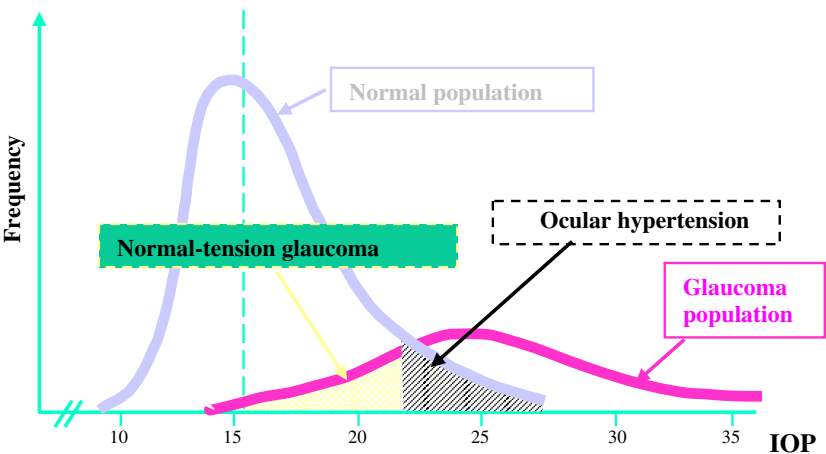

Fig. 3 Although increased IOP is a well-known risk factor, the IOP values of normal-tension glaucoma patients are within statistical norm 
antibodies to retina and optic nerve proteins; these alterations in the cellular subset indicate that the immune system plays an important role in the initiation and/or progression of glaucomatous optic neuropathy [25]. Therefore, serum antibodies to retina and optic nerve proteins might be considered as potential indicators for the diagnosis of glaucoma pathology [26]. In addition, it has been demonstrated that gene expression patterns of both trabecular meshwork and Schlemm's canal are similar to those of circulating leucocytes (CL) [27]. Moreover, blood serum is the biggest reservoir of signalling molecules in human beings: many metabolites are simultaneously secreted from different types of cells in blood that represents a universal way of communication between cells. Although this communication is extremely complex, one of the known natural sensors affected by the tremendous number of metabolites present in blood serum is CL. The spectrum of the molecules affecting expression patterns in CL is very broad and partially unknown; their regulation is extremely complex and not yet completely understood. However, it is known that the resulting regulation of $\mathrm{CL}$ is triggered by altered gene expression patterns on the levels of transcription and translation. The resulting shift in a gene expression pattern referred to a corresponding physiologic/pathologic condition
Fig. 4 Protein expression patterns characteristic for circulating leucocytes of glaucoma patients [30]. a. 2D-PAGE images of differential gene expression patterns in circulating leucocytes of glaucoma patients versus controls with particular changes marked. b. The scheme represents summarised results from the evaluation of comparative 2D-PAGE images. 132 protein spots were constantly present in all control images, whereby 75 spots were expressed at the same level. 133 protein spots were constantly present in patient images, whereby 52 spots were expressed at the same level. 17 proteins represent the overlap between 75 and 52 protein spots. Thirty spots were present only in the control group whereas 14 spots were present only in the patient group; all spots were detectable only in single images and, therefore, were not included in the above 133 and 132 pools. c. Quantitative analysis of 2D-PAGE images: among 75 and 52 conserved protein spots in the control and patient groups, respectively, 17 overlapping protein spots were found to be conserved for members of the same group. Corresponding expression levels in the control group are taken as standard $(=1)$. 9 proteins have been identified as given in the table

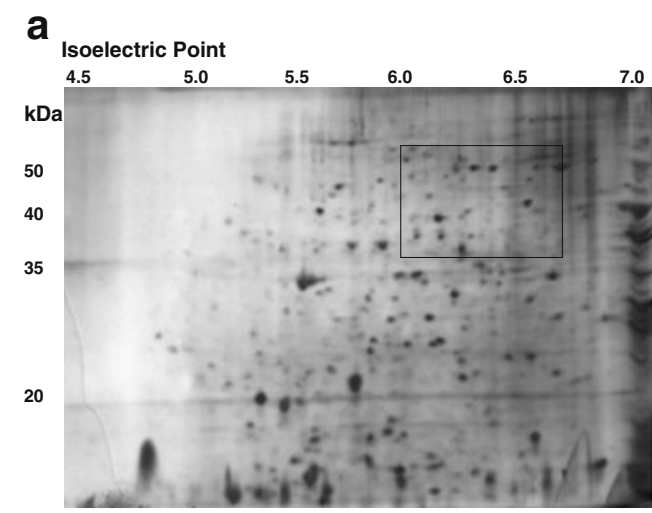

Control

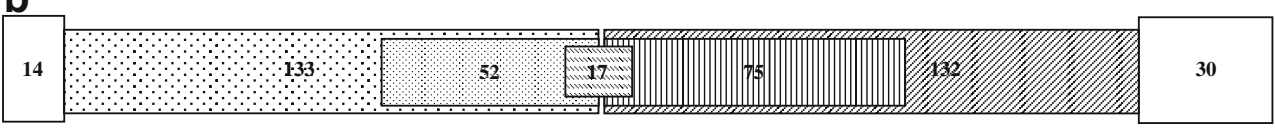

C

\begin{tabular}{|c|c|c|c|c|c|c|}
\hline $\begin{array}{c}\text { Control } \\
\text { group }\end{array}$ & $\begin{array}{l}\text { Glaucoma } \\
\text { group }\end{array}$ & $\begin{array}{l}\text { NCBI / } \\
\text { Acc. No }\end{array}$ & $\begin{array}{c}\text { Protein } \\
\text { identified }\end{array}$ & $\begin{array}{c}\text { Peptide Number } \\
\text { Measured/Matched }\end{array}$ & $\begin{array}{c}\text { Sequence } \\
\text { coverage }(\%)\end{array}$ & $\begin{array}{l}\text { Potential } \\
\text { function }\end{array}$ \\
\hline$=1$ & $1.6 \uparrow$ & $\begin{array}{c}\text { HSP70_HUMAN } \\
\text { AAB06397 }\end{array}$ & HSP70 & $47 / 18$ & 35 & $\begin{array}{l}\text { Stress } \\
\text { protein }\end{array}$ \\
\hline$=1$ & $2.0 \uparrow$ & $\begin{array}{l}\text { AP-2 beta } \\
\text { CAA64990 }\end{array}$ & $A P-2 \beta$ & $22 / 19$ & 55 & $\begin{array}{c}\text { Basic } \\
\text { transcription } \\
\text { regulator }\end{array}$ \\
\hline$=1$ & 1 & $\begin{array}{c}\text { K1C10_HUMAN } \\
\text { P13645 }\end{array}$ & Cytokeratin 10 & $31 / 21$ & 69 & $\begin{array}{l}\text { Cytoskeletal } \\
\text { protein }\end{array}$ \\
\hline$=1$ & $3.4 \downarrow$ & $\begin{array}{c}\text { ATPB_HUMAN } \\
\text { P06576 }\end{array}$ & $\begin{array}{l}\text { ATP synthase } \\
\text { beta chain, } \\
\text { mitochondrial } \\
\text { precursor }\end{array}$ & $55 / 14$ & 27 & $\begin{array}{c}\text { Energy } \\
\text { metabolism }\end{array}$ \\
\hline$=1$ & 1 & $\begin{array}{c}\text { ACTB_HUMAN } \\
\text { P60709 }\end{array}$ & Beta-actin & $34 / 19$ & 59 & $\begin{array}{c}\text { Cytoskeletal } \\
\text { protein }\end{array}$ \\
\hline$=1$ & $2.7 \uparrow$ & $\begin{array}{c}\text { GSTP1-HUMAN } \\
\text { P09211 }\end{array}$ & $\begin{array}{l}\text { Glutathione } S \text { - } \\
\text { transferase } P\end{array}$ & $11 / 8$ & 46 & $\begin{array}{l}\text { Red-ox } \\
\text { control }\end{array}$ \\
\hline$=1$ & $1.6 \uparrow$ & $\begin{array}{c}\text { PDIA1_HUMAN } \\
\text { P07237 }\end{array}$ & $\begin{array}{l}\text { Protein } \\
\text { disulfide- } \\
\text { isomerase } \\
\text { precursor }\end{array}$ & $18 / 6$ & 21 & $\begin{array}{l}\text { Stress- } \\
\text { response } \\
\text { protein }\end{array}$ \\
\hline$=1$ & 1 & $\begin{array}{c}\text { PROF1_HUMAN } \\
\text { P07737 }\end{array}$ & Profilin 1 & $13 / 5$ & 24 & $\begin{array}{l}\text { Cytoskeletal } \\
\text { protein }\end{array}$ \\
\hline$=1$ & 1 & $\begin{array}{c}\text { ACTG_HUMAN } \\
\text { P63261 }\end{array}$ & Gamma-actin & $31 / 16$ & 38 & $\begin{array}{l}\text { Cytoskeletal } \\
\text { protein }\end{array}$ \\
\hline
\end{tabular}

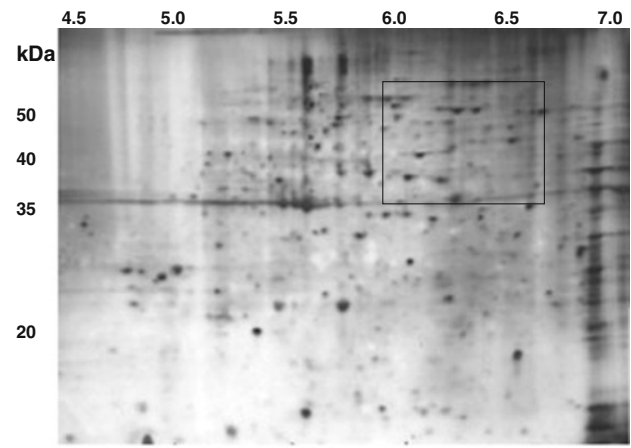

Glaucoma

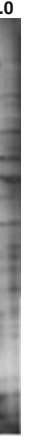


can be measured on both levels. Both vascular and immune components may play a role in pathomechanisms of glaucoma [28]. Taking the above into consideration, the search for disease specific gene expression patterns in glaucoma is of great value for a better understanding of the molecular pathomechanisms and creation of predictive approaches in glaucoma diagnostics.

\section{Key molecular pathways affected by glaucoma pathology: development of predictive diagnostic strategies}

Key molecular pathways affected by glaucoma pathology have been recently summarised in the book specifically dedicated to predictive diagnostics and personalised treatment [29].

The majority of molecules altered in glaucoma belong to well-defined functional gene-groups which, altogether, represent molecular pathways affected by the pathology (see Fig. 4).

\section{Stress response, apoptosis and DNA-repair}

An increased oxidative stress has been well documented under glaucoma pathology. Many oxidatively modified proteins were demonstrated in retinal protein lysates from ocular hypertensive eyes of rat-model of glaucoma [31]. Consequently, altered gene expression patterns, particularly for stress response factors, can be expected. Thus, the alteration of heat shock $27 \mathrm{kDa}$ protein 1 expression was stable in the retina of rat hypertensive eyes [32]. "Gene hunting" technology of "Subtractive Hybridisation" followed by quantification of target transcripts (see Fig. 5) performed in CL of glaucoma patients revealed an upregulation of both the pro-apoptotic factor $p 53$ and proteolytic enzyme 20S proteasome subunit XAPC7 [1], activity of which is usually increased during reperfusion [33]. In agreement with this, both an apoptotic inhibitor survivin and DNA-repair Xeroderma pigmentosum gene C have been found to be down-regulated in CL of glaucoma patients [1]. Moreover, ex vivo subcellular imaging by "Comet Assay"-analysis demonstrates significantly increased (un-repaired) DNA-damage in circulating leucocytes of both normal- and high-tension glaucoma patients $[29,35]$.

Adhesion, blood-brain-barrier (BBB)-breakdown and tissue remodelling

Gene expression profiles characteristic for an activated adherent function have been identified in CL of glaucoma patients: up-regulated transcripts of lymphocyte-IgE-receptor (Fc-epsilon-RII/CD23), T cell-specific tyrosine kinase (ITK), a

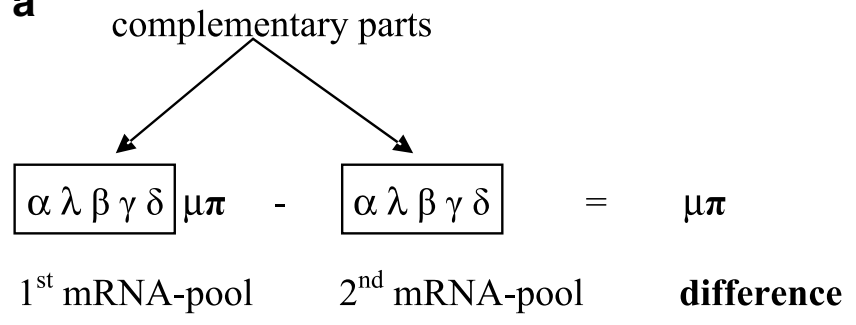

b

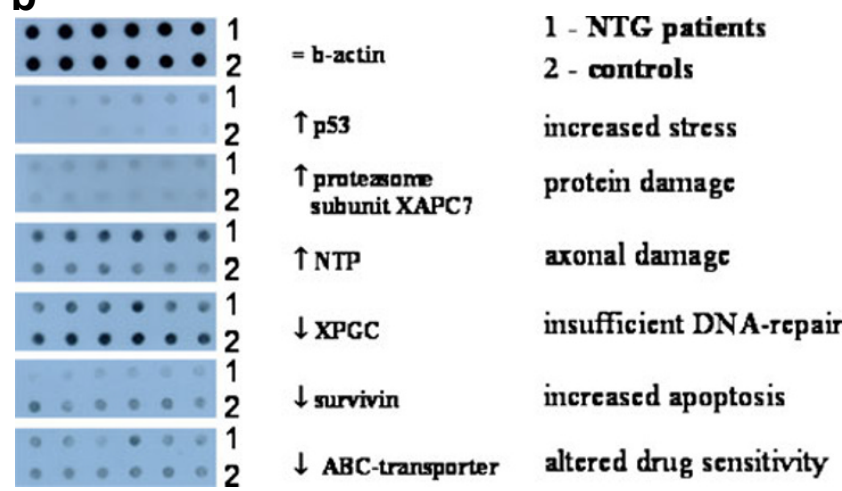

Fig. 5 a. Principle of "gene hunting" by the "Subtractive Hybridisation" $[1,34]$. Each mRNA-pool consists of individual gene transcripts, which undergo a comparison by hybridisation of identical (complementary) parts. The subtraction results in identification of non-complementary transcripts differentially expressed in two pools of comparison; the technology enables a consideration of both qualitative (present or absent) and quantitative (amount of copies per unit weight of mRNA in the corresponding pool) differences $\mathbf{b}$. Consequent quantification of the target transcripts (mRNA "Dot-Blot"-analysis), further provided a strong indication for increased stress, apoptosis, protein damage and axonal damage as well as insufficient DNA-repair and altered drugsensitivity in patients with glaucoma compared to the control group

thromboxan-A2-receptor, and alkaline-phosphatase have been detected by "subtractive hybridisation" [36]. Adherent circulating leucocytes (CL) could be an important contributor to BBB-breakdown observed in glaucoma pathology [37]. The subtraction of metalloproteinase MMP-9 and MT1-MMP transcripts highly increased in CL of glaucoma patients provides further evidence for this functional link and indicates pathways involved in the extensive tissue remodelling observed in glaucoma [38]. Significantly increased protein expression rates of both latent and active forms of $M M P-9$ and $M T 1-M M P$ in CL correlated well with the enhanced levels of transcription and with glaucoma [38]. Once activated, both hydrolases necessarily contribute to remod elling or even degeneration of the tissue whereto they are secreted by CL. This up-regulation might be a consequence of repeated mild ischemia/reperfusion postulated for glaucoma patients. However, the question as to whether or not there is a correlation between an increased MMPs activity and glaucoma severity should be further clarified. Recently performed comparative gene transcription profiling in trabecular mesh- 
work isolated from post-mortem glaucomatous eyes revealed a significant up-regulation of several cell adhesion molecules including platelet endothelial cells adhesion molecule-1 and $P$-selectin [39]. An enhanced deposition of the cell aggregation protein cochlin in trabecular meshwork and Schlemm's canal of glaucomatous eye supports the crucial role of cellular adhesion in glaucoma pathology and favours cell adhesion molecules as potential disease biomarkers [40].

\section{Transcription regulation}

Dramatically altered transcription patterns in glaucoma were reported by several research groups $[1,30,32,38]$. A reason for this extensive shift in transcription regulation was unclear for a very long time till a significant upregulation of the basic transcriptional regulator $A P-2 \beta$ was attributed to glaucoma pathology: $A P-2 \beta$ has been identified in CL using the smart technology of disease proteomics [30]. Protein mapping is demonstrated in Fig. 4a. AP-2 proteins play a decisive role, particularly in eye morphogenesis. While the activation of $A P-1$ leads to an increased stromelysin (metalloproteinase-3) production in trabecular meshwork in vitro [41, 42], the expression and activity of $A P-2$ controls the activity of the gelatinase $B(M M P-9)$ [43]. In consensus, $M M P-9$ was demonstrated to be significantly up-regulated in leucocytes of glaucoma patients and to play an important role in tissue remodelling as a part of glaucomatous degeneration [38]. Therefore, the concerted up-regulation of $A P-2 \beta$ and $M M P-9$ in leucocytes of glaucoma patients has been proposed to be an important part of the molecular mechanisms in glaucoma pathology and a reliable biomarker for diagnostic purposes.

\section{Multidrug resistance}

An extensive deregulation of $A B C$-transporters has been demonstrated in glaucoma pathology $[1,44,45]$. $A B C$ transporters (ATP-binding cassette transporter) usually translocate a wide variety of structurally unrelated lipophilic compounds being responsible for drug efflux, and therefore, for multidrug resistance. $A B C 1$ has been shown to be stably up-regulated in CL of glaucoma patients [45]. Joyce et al. demonstrated a crucial role for $A B C 1$ in protection against atherosclerosis [46]. An activity of $A B C 1$ has been shown to have a regulating effect on endothelial function and stimulate nitric oxide bioactivity in arterial walls [47]. The up-regulation of $A B C 1$ in $\mathrm{CL}$ of glaucoma patients might indicate the involvement of this gene in chronic vascular deregulation frequently observed in glaucoma pathology, and has been suggested as a potential marker for early diagnostics of glaucoma [45].

\section{Energy metabolism}

"Gene hunting" in CL of glaucoma patients revealed downregulated transcripts of $\mathrm{Na}^{+} / \mathrm{K}^{+}$-ATPase [36]. An identification of the subtracted transcripts is demonstrated in Fig. 2. Further, abnormal sodium handling has been

Table 1 Types of glaucoma-specific molecular alterations that can be potentially used for development of advanced tools for early and predictive diagnosis [60]

\begin{tabular}{|c|c|c|}
\hline Type of molecule & Possible type of alteration & Detection technology \\
\hline \multirow{4}{*}{$\begin{array}{l}\text { Chromosomal DNA, mitochondrial } \\
\text { DNA }\end{array}$} & 1. (Oxidative) damage ${ }^{a}$ & - Comet assay \\
\hline & 2. Mutations ${ }^{\mathrm{a}}$ & - Disease genomics \\
\hline & 3. Polymorphism ${ }^{\mathrm{a}}$ & - PCR, Restriction analysis, etc. \\
\hline & 4. Methylation status of $\mathrm{CpG}$ islands ${ }^{\mathrm{b}}$ & - Methylation-specific PCR \\
\hline \multirow[t]{2}{*}{ mRNA } & 1. Multiple alterations in expression patterns ${ }^{\mathrm{a}}$ & $\begin{array}{l}\text { - Disease transcriptomics: Subtractive hybridisation } \\
\text { Expression array, Reverse-Transcriptase-PCR, } \\
\text { Real-Time-PCR, etc. }\end{array}$ \\
\hline & 2. Reduced mRNA editing & - Reverse-Transcriptase-PCR \\
\hline \multirow[t]{4}{*}{ Proteins } & 1. Multiple alterations in expression patterns ${ }^{\mathrm{a}}$ & $\begin{array}{l}\text { - Disease Proteomics: 2D-PAGE, MALDI-TOF, } \\
\text { Western-blot, etc. }\end{array}$ \\
\hline & 2. Posttranslational modification ${ }^{a}$ & $\begin{array}{l}\text { - Western-blot, Activity tests (e.g. Zymography } \\
\text { for gelatinases) }\end{array}$ \\
\hline & 3. Phosphorylation status ${ }^{\mathrm{a}}$ & - Activity tests \\
\hline & 4. Protein misfolding ${ }^{a}$ & - Activity tests \\
\hline $\begin{array}{l}\text { Metabolites (signalling molecules, } \\
\text { amino acids, plasma hormones, etc.) }\end{array}$ & Altered profiles ${ }^{a}$ & $\begin{array}{l}\text { Disease Metabolomics: Comparative blood plasma } \\
\text { metabolites profiling, HPLC, Activity tests, etc. }\end{array}$ \\
\hline
\end{tabular}

${ }^{\mathrm{a}}$ Types of molecular alterations reported for glaucoma pathology. ${ }^{\mathrm{b}}$ Data indicating this kind of alteration collected in our laboratory, which, however, have not been published until now 
proposed to be associated with ocular hypertensivity and to contribute to a progression of the optic nerve damage in both normal-tension and high-tension glaucoma [48, 49]. $\mathrm{Na}^{+} / \mathrm{K}^{+}$-ATPase is known to be down-regulated in lymphocytes of patients with acute myocardial infarction [50], and may be one of the reasons for ventricular arrhythmias and coronary artery spasms. A decrease in intracellular potassium concentration and an increase in intracellular calcium concentration may play a major role in the pathomechanism of coronary artery spasms. Inhibition of $\mathrm{Na}^{+} / \mathrm{K}^{+}$-ATPase is one of functional consequences of oxidative membrane damage caused by an increased oxidative stress [51], which is triggered e.g. under ischemia/reperfusion. This affects central thermogenic mechanisms, since $\mathrm{Na}^{+} / \mathrm{K}^{+}$-ATPase has been shown to play a key role in cellular energy balance and thermogenesis $[52,53]$. A decreased activity of $\mathrm{Na}^{+} /$ $K^{+}$-ATPase triggers vasospasm [54]. Being an important co-factor of cellular ATPases, magnesium can reverse delayed vasospasm and reduce the extent of acute ischemic lesions [55]. Magnesium therapy demonstrates beneficial effects in vasospastic syndrome and glaucoma [9].

\section{Effect of glaucoma medication on the evaluation of biomarkers}

Evaluation of glaucoma biomarkers under treatment conditions is a particular issue in glaucoma research. Indeed, can we use the markers proposed for diagnostics of untreated glaucoma also under glaucoma medication? Are there any reliable markers which can predict the outcome of glaucoma treatment? There are some studies clearly demonstrating that glaucoma medication may definitely mask alterations in crucial biomarkers such as those of the nitric oxide pathway [56]. Additionally, toxic side effects of anti-glaucoma drugs on conjunctiva have been reported: histological studies of conjunctival tissues in patients who underwent a long-term glaucoma treatment demonstrated an abnormal infiltration of inflammatory cells. Consequently, an abnormal expression of inflammatory markers under various anti-glaucomatous treatments has been shown [57].

Much progress has been achieved in the development of markers that can potentially predict the outcome of glaucoma surgery. In the research of Souchier et al., surgery success was defined as reduced IOP $\leq 15 \mathrm{~mm} \mathrm{Hg}$ without any IOP-lowering drugs at 6 months. Conjunctival expression levels of trefoil factor family 1 (TFF1) and MUC5AC as well as $H L A-D R$ in leucocytes have been measured [58] and an increased expression of all three molecular markers has been proposed as a potential prediction factor for successful glaucoma surgery. However, the issue of glaucoma medication markers is a multifarious one and requires more research effort.

\section{Perspectives for application of most potent biotechnological tools}

High-accuracy proteome maps of human body fluids open new perspectives for early molecular diagnostics of chronic disorders. Abundant scientific evidence from disease proteomics suggests that disease specific protein expression patterns in blood are indicative of many-if not mosthuman disorders, and might be a powerful tool for early molecular diagnostics of glaucomatous damage. A noninvasive molecular diagnostic approach based on disease specific gene expression patterns in CL has been suggested for glaucoma [59]. The test foresees a precise expression profiling of selected genes in CL isolated from fresh blood samples. These genes (gene products) have been proposed to play a role in glaucoma pathology and belong to following pathways: an apoptosis, stress response, DNA-repair, transcription regulation, multidrug resistance, tissue remodelling and degeneration. Currently a clinical application of the test is under consideration, and a nanotechnology which should provide a possibly easy and cheap routine application of the test is under development. Possible types of molecular alterations that can be considered for predictive glaucoma diagnosis and corresponding detection technologies are summarised in Table 1.

\section{References}

1. Golubnitschaja-Labudova O, Liu R, Decker C, et al. Altered gene expression in lymphocytes of patients with normal-tension glaucoma. Curr Eye Res. 2000;21:867-76.

2. de la Monte SM, Xu YY, Hutchins GM, et al. Developmental patterns of neuronal thread protein gene expression in Down syndrome. J Neurol Sci. 1996;135:118-25.

3. Tatton W, Chen D, Chalmers-Redman R, et al. Hypothesis for a common basis for neuroprotection in glaucoma and Alzheimer's disease: anti-apoptosis by alpha-2-adrenergic receptor activation. Surv Ophthalmol. 2003;48:S25-37.

4. Quigley HA. Number of people with glaucoma worldwide. Br J Ophthalmol. 1996;80:389-93.

5. Flammer J. Glaucoma. A guide for patients. An introduction for careproviders. A quick reference. Hogrefe \& Huber Publishers; 2003.

6. Gugleta K, Orgül S, Flammer J. Asymmetry in intraocular pressure and retinal nerve fiber layer thickness in normal-tension glaucoma. Ophthalmologica. 1999;213:219-23.

7. Hayreh SS, Podhajsky P, Zimmerman MB. Role of nocturnal arterial hypotension in optic nerve head ischemic disorders. Ophthalmologica. 1999;213:76-96.

8. Reddy AB, Panicker SG, Mandal AK, et al. Identification of R368H as a predominant CYP1B1 allele causing primary congenital glaucoma in Indian patients. Investig Ophthalmol Vis Sci. 2003;44: 4200-3.

9. Kanagavalli J, Krishnadas SR, Pandaranayaka E, et al. Evaluation and understanding of myocilin mutations in Indian primary open angle glaucoma patients. Mol Vis. 2003;14:606-14.

10. Gong G, Kosoko-Lasaki O, Haynatzki GR, et al. Genetic dissection of myocilin glaucoma. Hum Mol Genet. 2004;3:R91-102. 
11. Mardin CY, Velten I, Ozbey S, et al. A GLC1A gene Gln368Stop mutation in a patient with normal-tension open-angle glaucoma. J Glaucoma. 1999;8:154-6.

12. Colomb E, Kaplan J, Garchon HJ. Novel cytochrome P450 1B1 (CYP1B1) mutations in patients with primary congenital glaucoma in France. Hum Mutat. 2003;22:496.

13. Howell N. LHON and other optic nerve atrophies: the mitochondrial connection. Dev Ophthalmol. 2003;37:94-108.

14. Leung YF, Fan BJ, Lam DS, et al. Different optineurin mutation pattern in primary open-angle glaucoma. Investig Ophthalmol Vis Sci. 2003;44:3880-4.

15. Mackey DA, Craig JE. Predictive DNA testing for glaucoma: reality in 2003. Ophthalmol Clin N Am. 2003;16:639-45.

16. Polansky JR. Current perspectives on the TIGR/MYOC gene (Myocilin) and glaucoma. Ophthalmol Clin North Am. 2003;16: 515-27. v-vi.

17. Panicker SG, Mandal AK, Reddy AB, et al. Correlations of genotype with phenotype in Indian patients with primary congenital glaucoma. Investig Ophthalmol Vis Sci. 2004;45:1149-56.

18. Herndon LW, Challa P, Allingham RR. Glaucoma in Ghana, West Africa: clinical features and the role of mutations in Myocilin. Ophthalmol Clin N Am. 2003;16:631-7.

19. Bruttini M, Longo I, Frezzotti P, et al. Mutations in the myocilin gene in families with primary open-angle glaucoma and juvenile open-angle glaucoma. Arch Ophthalmol. 2003;121:1034-8.

20. Melki R, Idhajji A, Driouiche S, et al. Mutational analysis of the Myocilin gene in patients with primary open-angle glaucoma in Morocco. Ophthalmic Genet. 2003;24:153-60.

21. Wiggs JL, Auguste J, Allingham RR, et al. Lack of association of mutations in optineurin with disease in patients with adultonset primary open-angle glaucoma. Arch Ophthalmol. 2003;121: 1181-3.

22. Sripriya S, Uthra S, Sangeetha R, et al. Low frequency of myocilin mutations in Indian primary open-angle glaucoma patients. Clin Genet. 2004;65:333-7.

23. Yeghiazaryan K, Flammer J, Orgül S, et al. Vasospastic individuals demonstrate significant similarity to glaucoma patients as revealed by gene expression profiling in circulating leukocytes. Mol Vis. 2009;15:2339-48.

24. Yeghiazaryan K, Flammer J, Golubnitschaja O. Predictive molecular profiling in blood of healthy vasospastic individuals: clue to targeted prevention as personalised medicine to effective costs. The EPMA Journal. 2010;2.

25. Yang J, Patil RV, Yu H, et al. T cell subsets and sIL-2R/IL-2 levels in patients with glaucoma. Am J Ophthalmol. 2001;131:421-6.

26. Grus FH, Joachim SC, Bruns K, et al. Serum autoantibodies to alpha-fodrin are present in glaucoma patients from Germany and the United States. Investig Ophthalmol Vis Sci. 2006;47:968-76.

27. Tomarev SI, Wistow G, Raymond V, et al. Gene expression profile of the human trabecular meshwork: NEIBank sequence tag analysis. Investig Ophthalmol Vis Sci. 2003;44:2588-96.

28. Flammer J, Mozaffarieh M. What is the present pathogenetic concept of glaucoma? Surv Ophthalmol. 2007;52 Suppl 2:S162-73.

29. Golubnitschaja O, Yeghiazaryan K, Orgül S, et al. What are the biomarkers for Glaucoma? In: Golubnitshaja O, editor. Predictive diagnostics and personalized treatment: dream or reality. New York: Nova Science; 2009. p. 375-96.

30. Golubnitschaja O, Yeghiazaryan K, Wunderlich K, et al. Disease proteomics reveals altered basic gene expression regulation in leukocytes of glaucoma patients. Proteomics Clin Appl. 2007;1: 1316-23.

31. Tezel G, Yang X, Cai J. Proteomic identification of oxidatively modified retinal proteins in a chronic pressure-induced rat model of glaucoma. Investig Ophthalmol Vis Sci. 2005;46:3177-87.

32. Ahmed F, Brown KM, Stephan DA, et al. Microarray analysis of changes in mRNA levels in the rat retina after experimental elevation of intraocular pressure. Investig Ophthalmol Vis Sci. 2004:45:1247-58.

33. Wunderlich $\mathrm{K}$, Golubnitschaja $\mathrm{O}$, Pache $\mathrm{M}$, et al. Increased plasma levels of $20 \mathrm{~S}$ proteasome alpha-subunit in glaucoma patients: an observational pilot study. Mol Vis. 2002;8:431-5.

34. Golubnitschaja O, Fountoulakis M. Gene hunting by substractive hybridisation in Down syndrome. Correlation with proteomics analysis. In: Mandel S, editor. Genomics, proteomics and the nervous system. 3rd ed. Berlin-Heidelberg: Springer; 2007.

35. Moenkemann H, Flammer J, Wunderlich K, et al. Increased DNA breaks and up-regulation of both $\mathrm{G}(1)$ and $\mathrm{G}(2)$ checkpoint genes p21(WAF1/CIP1) and 14-3-3 sigma in circulating leukocytes of glaucoma patients and vasospastic individuals. Amino Acids. 2005;28:199-205.

36. Golubnitschaja O, Wunderlich K, Decker C, et al. Molecular imaging of perfusion disturbances in glaucoma. Amino Acids. 2002;23:293-9.

37. Grieshaber MC, Flammer J. Does the blood-brain-barrier play a role in Glaucoma? Surv Ophthalmol. 2007;52 Suppl 2:S144-54.

38. Golubnitschaja $\mathrm{O}$, Yeghiazaryan $\mathrm{K}$, Liu $\mathrm{R}$, et al. Increased expression of matrix metalloproteinases in mononuclear blood cells of normal-tension glaucoma patients. J Glaucoma. 2004;13: 66-72.

39. Diskin S, Kumar J, Cao Z, et al. Detection of differentially expressed glycogenes in trabecular meshwork of eyes with primary open-angle glaucoma. Investig Ophthalmol Vis Sci. 2006; 47:1491-9.

40. Bhattacharya SK, Rockwood EJ, Smith SD, et al. Proteomics reveal Cochlin deposits associated with glaucomatous trabecular meshwork. J Biol Chem. 2005;280:6080-4.

41. Fleenor DL, Pang IH, Clark AF. Involvement of AP-1 in interleukin1alpha-stimulated MMP-3 expression in human trabecular meshwork cells. Investig Ophthalmol Vis Sci. 2003;44:3494-501.

42. Pang IH, Fleenor DL, Hellberg PE, et al. Aqueous outflowenhancing effect of tert-butylhydroquinone: involvement of AP-1 activation and MMP-3 expression. Investig Ophthalmol Vis Sci. 2003;44:3502-10.

43. Mohan R, Rinehart WB, Bargagna-Mohan P, et al. Gelatinase B/ lacZ transgenic mice, a model for mapping gelatinase $\mathrm{B}$ expression during developmental and injury-related tissue remodeling. J Biol Chem. 1998;273:25903-14.

44. Esser J, Esser P, Mietz H, et al. Multidrug resistance-associated proteins in glaucoma surgery. Graefes Arch Clin Exp Ophthalmol. 2000;238:727-32.

45. Yeghiazaryan K, Flammer J, Wunderlich K, et al. An enhanced expression of $\mathrm{ABC} 1$ transporter in circulating leukocytes as a potential molecular marker for the diagnostics of glaucoma. Amino Acids. 2005;28:207-11.

46. Joyce CW, Amar MJ, Lambert G, et al. The ATP binding cassette transporter A1 (ABCA1) modulates the development of aortic atherosclerosis in C57BL/6 and apoE-knockout mice. Proc Natl Acad Sci USA. 2002;99:407-12.

47. Bisoendial RJ, Hovingh GK, Levels JH, et al. Restoration of endothelial function by increasing high-density lipoprotein in subjects with isolated low high-density lipoprotein. Circulation. 2003;107:2944-8.

48. Pechere-Bertschi A, Sunaric-Megevand G, Haefliger IO, et al. Renal sodium handling in patients with normal pressure glaucoma. Clin Sci (Lond). 2007;112:337-44.

49. Schwartz B, Abrahamson R, Takamoto T, et al. Association of ocular pressure and optic disc cup volume with red blood cell sodium-potassium ATPase inhibition. Curr Eye Res. 2000;21: 897-905.

50. Salomon P, Mysiak A, Halawa B. Sodium efflux through lymphocytic cell membranes in patients with acute myocardial infarction. Pol Arch Med Wewn. 1998;100:543-50. 
51. Stark G. Functional consequences of oxidative membrane damage. J Membr Biol. 2005;205:1-16.

52. Silva JE. Thyroid hormone control of thermogenesis and energy balance. Thyroid. 1995;5:481-92.

53. Valdemarsson S, Ikomi-Kumm J, Monti M. Increased lymphocyte thermogenesis in hyperthyroid patients. Role of $\mathrm{Na} / \mathrm{K}$ pump function. Evaluation of aerobic/anaerobic metabolism. Acta Endocrinol (Copenh). 1992;126:291-5.

54. Bagrov AY, Dmitrieva RI, Fedorova OV, et al. Endogenous marinobufagenin-like immunoreactive substance. A possible endogenous $\mathrm{Na}$, K-ATPase inhibitor with vasoconstrictor activity. Am J Hypertens. 1996;9:982-90.

55. van den Bergh WM, Dijkhuizen RM, Rinkel GJ. Potentials of magnesium treatment in subarachnoid haemorrhage. Magnes Res. 2004;17:301-13.
56. Kotikoski H, Moilanen E, Vapaatalo H, et al. Biochemical markers of the L-arginine-nitric oxide pathway in the aqueous humour in glaucoma patients. Acta Ophthalmol Scand. 2002;80:191-5.

57. Baudouin C, Garcher C, Haouat N, et al. Expression of inflammatory membrane markers by conjunctival cells in chronically treated patients with glaucoma. Ophthalmology. 1994;101: 454-60.

58. Souchier M, Buron N, Lafontaine PO, et al. Trefoil factor family 1 , MUC5AC and human leucocyte antigen-DR expression by conjunctival cells in patients with glaucoma treated with chronic drugs: could these markers predict the success of glaucoma surgery? Br J Ophthalmol. 2006;90:1366-9.

59. Golubnitschaja O, Flammer J. International Patent No. IB02/00648

60. Golubnitschaja O, Flammer J. What are the biomarkers for glaucoma? Surv Ophthalmol. 2007;52:S155-61. 